\title{
Clinical impact of myocardial ischemia and viability after treatment of proximal left anterior descending artery chronic total occlusions
}

\author{
Cássio dos Santos Nunes ${ }^{1}$, Wilson Albino Pimentel Filho², Wellington Borges Custódio ${ }^{3}$, \\ Gustavo Vinicius Lambert Olivotti ${ }^{4}$, Carlos Alberto Sada ${ }^{5}$, Thomas Edison Cintra Osterne ${ }^{6}$, \\ Fernando Augusto Molinori di Castro Curado 7 , Waigner Bento Pupin Filho ${ }^{8}$, Milton Macedo Soares Neto ${ }^{9}$, \\ Jorge Roberto Büchler ${ }^{10}$, Stoessel Figueredo de Assis ${ }^{11}$
}

\begin{abstract}
Background: Evaluation of myocardial ischemia and viability is recommended prior to percutaneous coronary intervention (PCI) for chronic total occlusions. We evaluated late adverse cardiovascular events of patients with $\mathrm{PCl}$ for proximal left anterior descending artery occlusions, comparing patients with or without myocardial ischemia or viability. Methods: Patients were allocated to groups with myocardial ischemia/ viability (G1, $\mathrm{n}=91$ ) and without myocardial ischemia/ viability $(\mathrm{G} 2, \mathrm{n}=65)$ and adverse cardiovascular events (death, myocardial infarction, target-vessel revascularization and congestive heart failure) were compared. Results: Most patients were male $(68.1 \%$ vs $69.2 \%$; $P=0.56)$, with a mean age of $65.4 \pm 10$ years vs $63.5 \pm 8.7$ years $(\mathrm{P}=$ 0.61 ) and almost one third were diabetics (33\% vs $29.2 \%$; $P=0.76)$. No differences regarding the clinical and angiographic profile were observed, except for the left ventricular ejection fraction $(48.6 \pm 13.7 \%$ vs $39.5 \pm 11.8 \%$; $\mathrm{P}=0.04)$ and the degree of angiographic collateral flow grade to the left anterior descending artery, which was more evident in $\mathrm{G} 1$ ( $\mathrm{P}=0.03)$. The 3-year follow-up incidence of composite adverse cardiovascular events was lower in patients with myocardial ischemia/viability $(12.5 \%$ vs $31.1 \%$; $\mathrm{P}<$ $0.01)$. The factors that contributed the most for this difference were the incidence of congestive heart failure $(3.3 \%$ vs $15.3 \% ; P=0.02)$ and death $(2.2 \%$ vs $7.7 \% ; P=0.13)$. Conclusions: Treatment of proximal left anterior descending artery chronic total occlusions in patients with evidence of
\end{abstract}

RESUMO

Impacto Clínico da Isquemia e Viabilidade
Miocárdicas após Tratamento de Oclusão Coronária
Crônica no Segmento Proximal da Artéria
Descendente Anterior

Introdução: A avaliação da isquemia e viabilidade miocárdicas é recomendável antes da intervenção coronária percutânea (ICP) em oclusões crônicas. Avaliamos os eventos cardiovasculares adversos tardios de pacientes com ICP da oclusão crônica no segmento proximal da artéria descendente anterior, comparando pacientes de acordo com a presença ou não de isquemia ou viabilidade miocárdicas. Métodos: Os pacientes foram alocados nos grupos com isquemia/viabilidade miocárdicas (G1, n = 91) e sem isquemia/viabilidade miocárdicas $(G 2, n=65)$ e avaliados os eventos clínicos combinados tardios (óbito, infarto do miocárdio, revascularização do vaso-alvo e insuficiência cardíaca congestiva). Resultados: A maioria dos pacientes era do sexo masculino $(68,1 \%$ vs. $69,2 \%$; $P=0,56)$, com média de idade de $65,4 \pm 10,4$ anos vs. $63,5 \pm 8,7$ anos $(P=0,61)$, e quase um terço era de diabéticos $(33 \%$ vs. 29,2\%; $\mathrm{P}=$ $0,76)$. Os grupos não mostraram diferenças em relação ao perfil clínico-angiográfico, com exceção da fração de ejeção do ventrículo esquerdo $(48,6 \pm 13,7 \%$ vs. $39,5 \pm 11,8 \% ; \mathrm{P}=$ $0,04)$ e do grau de circulação colateral para a artéria descendente anterior, mais evidente no $G 1(P=0,03)$. A incidência de eventos clínicos combinados em um período de três anos foi menor nos pacientes com isquemia/viabilidade miocárdicas

\footnotetext{
${ }^{1}$ Resident physician at Hospital Beneficência Portuguesa de São Paulo. São Paulo, SP, Brazil.

2 Doctor. Director of the Interventional Cardiology Team-Wilson Pimentel do Hospital Beneficência Portuguesa de São Paulo. São Paulo, SP, Brazil.

${ }^{3}$ Interventionist cardiologist physician at Hospital Beneficência Portuguesa de São Paulo. São Paulo, SP, Brazil.

${ }^{4}$ Resident physician at Hospital Beneficência Portuguesa de São Paulo. São Paulo, SP, Brazil.

${ }^{5}$ Resident physician at Hospital Beneficência Portuguesa de São Paulo. São Paulo, SP, Brazil.

${ }^{6}$ Resident physician at Hospital Beneficência Portuguesa de São Paulo. São Paulo, SP, Brazil.

${ }^{7}$ Resident physician at Hospital Beneficência Portuguesa de São Paulo. São Paulo, SP, Brazil.
}

\footnotetext{
${ }^{8}$ Resident physician at Hospital Beneficência Portuguesa de São Paulo. São Paulo, SP, Brazil.

9 Master. Interventionist cardiologist physician at Hospital do Rim e Hipertensão da Universidade Federal de São Paulo (Unifesp). São Paulo, SP, Brazil.

${ }^{10}$ Doctor. Interventionist cardiologist physician at Hospital Beneficência Portuguesa de São Paulo. São Paulo, SP, Brazil.

11 Interventionist cardiologist physician at Hospital Beneficência Portuguesa de São Paulo. São Paulo, SP, Brazil.
}

Correspondence to: Wilson Albino Pimentel Filho. Rua Inhambú, 917 - ap. 91 - Moema - São Paulo, SP, Brazil - CEP 04520-013

E-mail: wilpm@uol.com.br

Received on: 2/24/2013 • Accepted on: 5/16/2013 
myocardial ischemia or viability reduces the incidence of adverse cardiovascular events in the long term.

DESCRIPTORS: Angioplasty. Drug-eluting stents. Coronary occlusion. Coronary angiography.

$\mathrm{T}$ he left anterior descending artery is responsible for irrigating most of the left ventricular musculature and, thus, severe atherosclerotic obstructive disease in its proximal segment is associated with worse prognosis. ${ }^{1}$ The left anterior descending artery is a turning point among clinical, percutaneous, and surgical treatments in obstructive coronary artery disease, especially when presenting as chronic coronary occlusion in its proximal segment. ${ }^{2}$ Even more challenging for several treatment modalities is the combination of chronic coronary occlusion of the left anterior descending artery and multivessel coronary disease, particularly in diabetic patients, in whom, in most cases, surgical treatment is preferred. ${ }^{2,3}$

Drug-eluting stents (DES) have shown significant reduction in restenosis and the need for a new intervention when compared to bare-metal stents (BMS). ${ }^{4-6}$ In the treatment of the left anterior descending artery proximal segment, it is notable the best clinical outcomes of patients treated with DES, when compared with those treated with $\mathrm{BMS},{ }^{7}$ with a similar clinical outcome to that of patients undergoing coronary artery bypass graft $(C A B G)$ surgery using graft from the left internal mammary artery to the left anterior descending artery. ${ }^{8}$ Particularly in patients with chronic coronary occlusion, ${ }^{9,10}$ and specifically in the proximal segment of the left anterior descending artery, ${ }^{11}$ the beneficial effect of DES on clinical outcomes in the long-term when compared to patients receiving BMS is indisputable; DES is recommended by Brazilian ${ }^{12}$ and international guidelines. ${ }^{13,14}$

Currently, percutaneous revascularization is an excellent option in the management of chronic coronary occlusion, but proper selection of patients and a careful assessment of the anatomical lesion aspects, the availability of devices dedicated to the management of occlusions, and the availability of DES are paramount. When selecting patients, it is recommended to evaluate, prior to procedure, the presence of ischemia and myocardium viability, which is associated with ventricular dysfunction regression after the recovery of coronary flow to the cardiac muscle area irrigated by the vessel. ${ }^{15,16}$ However, this recommendation is not always followed in daily clinical practice.
$(12,5 \%$ vs. $31,1 \%$; $P<0,01)$. Os fatores que mais contribuíram para essa diferença foram a incidência de insuficiência cardíaca congestiva ( $3,3 \%$ vs. $15,3 \%$; $P=0,02)$ e óbito $(2,2 \%$ vs. $7,7 \%$; $\mathrm{P}=0,13)$. Conclusões: $\mathrm{O}$ tratamento de oclusão crônica no segmento proximal da artéria descendente anterior com stent farmacológico, em pacientes com evidência de isquemia ou viabilidade miocárdicas, reduz eventos clínicos a longo prazo.

DESCRITORES: Angioplastia. Stents farmacológicos. Oclusão coronária. Angiografia coronária.

This study aimed to analyze the long-term results of patients successfully treated by percutaneous recanalization of chronic coronary occlusion with DES implantation in the left anterior descending artery proximal segment, comparing two different populations according to the presence or absence of ischemia or myocardial viability, related to the occurrence of late adverse cardiovascular events.

\section{METHODS}

\section{Patients}

From January 2001 to December 2012, 269 patients with chronic coronary occlusion in the left anterior descending artery proximal segment were treated in this hospital. Patients whose initial clinical presentation was acute myocardial infarction with ST-segment elevation or previous CABG were excluded. Of the 235 $(87.4 \%)$ successfully treated patients, $156(66.4 \%)$ had undergone ischemia and myocardial viability assessment. These patients were allocated into groups with ischemia/myocardial viability $(\mathrm{G} 1, \mathrm{n}=91)$ or without ischemia/myocardial viability $(\mathrm{G} 2, \mathrm{n}=65)$.

The study was performed according to the Declaration of Helsinki regarding research in human subjects and all patients signed an informed consent.

\section{Percutaneous coronary intervention}

Percutaneous coronary interventions (PCls) were performed in accordance with the current guidelines, ${ }^{12-14}$ and the final procedure strategy was left to the surgeon's discretion. In all patients, recanalization of the left anterior descending artery was performed by anterograde approach, and in 67 patients $(42.9 \%)$ right and left coronary artery angiography were performed simultaneously. These lesions were treated with DES, which did not occur with the additional vessels in patients with multivessel disease, who received DES or BMS.

During the procedure, unfractionated heparin was administered at a dose of $70 \mathrm{IU} / \mathrm{kg}$ to $100 \mathrm{IU} / \mathrm{kg}$, and the use of IIb/IIla glycoprotein inhibitors was left to the surgeon's discretion. Pre-dilation was not mandatory, 
and stent post-dilatation was recommended in case of residual stenosis $>20 \%$ by visual estimation.

Dual antiplatelet therapy consisted in the administration of $100 \mathrm{mg} /$ day of acetylsalicylic acid and 75 $\mathrm{mg} /$ day of clopidogrel. The administration of clopidogrel should be started at least 24 hours before the procedure, and a loading dose of $300 \mathrm{mg}$ (or $600 \mathrm{mg}$ if $\mathrm{PCl}<24$ hours) was recommended. After the $\mathrm{PCl}$, therapy with acetylsalicylic acid was maintained indefinitely thereafter, and clopidogrel was maintained for at least one year.

\section{Ischemia and myocardial viability study}

Two techniques for the assessment of ischemia and myocardial viability were used in the present study:

- Cardiac magnetic resonance imaging, ${ }^{17}$ performed with contractile reserve assessment with inotropic stimulation with dobutamine and complemented with late enhancement with gadolinium. The increased thickness of the myocardial wall induced by dobutamine is a good predictor of residual metabolic activity. The myocardial regions exhibiting delayed enhancement with gadolinium coincide with regions of myocardial necrosis and irreversible damage. Regions that do not exhibit this delayed enhancement are viable.

- Stress echocardiography with dobutamine, ${ }^{18}$ whose standard protocol consisted of a continuous infusion of dobutamine at an initial dose of $5 \mathrm{mcg} / \mathrm{kg} /$ min, followed by $10 \mathrm{mcg} / \mathrm{kg} / \mathrm{min}, 20 \mathrm{mcg} / \mathrm{kg} / \mathrm{min}, 30$ $\mathrm{mcg} / \mathrm{kg} / \mathrm{min}$, and $40 \mathrm{mcg} / \mathrm{kg} / \mathrm{min}$ every $3 \mathrm{~min}$. Atropine at fractionated doses of $0.5 \mathrm{mg}$, up to a total of $2 \mathrm{mg}$, could be administered, if necessary, to achieve the target heart rate (defined as $85 \%$ of the maximum heart rate calculated for age). The biphasic response, improved segmental contractility at lower doses of dobutamine and worsening with higher doses were considered indicative of myocardial viability and stress-induced ischemia, respectively.

The ischemia and myocardial viability were evaluated by dobutamine-stress echocardiography in $51.3 \%$ and by cardiac nuclear magnetic resonance in $48.7 \%$ of patients.

\section{Outcomes and clinical follow-up}

The primary study outcome was the occurrence of composite clinical events in the late follow-up, defined as cardiac death, nonfatal myocardial infarction, targetvessel revascularization, and congestive heart failure.

All deaths were considered cardiac, unless a noncardiac cause could be clearly established by clinical and/or pathological study. The diagnosis of myocardial infarction was based on the development of new pathological $\mathrm{Q}$ waves in > 2 contiguous ECG leads and/or elevation of CK-MB isoenzyme $>$ three-fold the upper normal limit after the procedure during the index hospitalization, or $>$ two-fold the upper normal limit after hospital discharge. All new revascularizations, whether surgical or percutaneous, were recorded.

Clinical follow-up was performed after the procedure, and consisted of telephone contact performed according to a predefined institutional protocol.

\section{Statistical Analysis}

Categorical variables were expressed as absolute numbers and percentages, and evaluated by chi-squared or Fisher exact tests when appropriate. Continuous variables were expressed as means and standard deviations and compared using Student's t-test. P-values $<0.05$ were considered statistically significant.

\section{RESULTS}

The clinical and angiographic characteristics of patients are summarized in Table 1. Most patients were males (68.1\% vs. $69.2 \%$; $P=0.56)$, with a mean age of $65.4 \pm 10.4$ years vs. $63.5 \pm 8.7$ years $(P=0.61)$; almost one-third were diabetics (33\% vs. 29.2\%; P = 0.76). Stable clinical pictures predominated, as well as multivessel coronary artery disease in the angiographic analysis. The groups did not present any differences, except for the left ventricular ejection fraction (48.6 \pm $13.7 \%$ vs. $39.5 \pm 11.8 \% ; P=0.04)$ and the degree of angiographic collateral flow grade to the left anterior descending artery, more evident in G1 ( $P=0.03)$.

DES were implanted in the left anterior descending artery in all patients; in multivessel disease patients, DES or BMS in the other coronary arteries. The DES implanted in the left anterior descending artery were, in two-thirds of cases (64.1\%), sirolimus- or paclitaxeleluting stents, and in the others, everolimus-, zotarolimus-, or biolimus-eluting stents. In patients with two-vessel involvement, 234 lesions were treated with two or more stents in $76.9 \%$ of cases, and with one stent in the others. In patients with three-vessel involvement, 390 lesions were treated with three or more stents in $60.8 \%$ of cases, and two stents in the remaining.

The incidence of composite clinical events during a three-year period was lower in patients with ischemia/ myocardial viability $(12.1 \%$ vs. $30.8 \%$; $P<0.01)$. The main factor that contributed to this difference was the incidence of congestive heart failure $(3.3 \%$ vs. $15.3 \%$; $\mathrm{P}=0.02)$ and death $(2.2 \%$ vs. $7.7 \% ; P=0.13)$. The other clinical events were similar between the groups. These data are presented in Table 2. Angiographic restenosis of the left anterior descending artery was detected in $6.6 \%$ vs. $6.2 \%(P>0.99)$.

\section{DISCUSSION}

This study demonstrated the long-term benefit of chronic coronary occlusion treatment in the left anterior descending artery proximal segment with DES 
TABLE 1

Clinical and angiographic characteristics of patients

\begin{tabular}{|c|c|c|c|}
\hline & G1 $(n=91)$ & $G 2(n=65)$ & P-value \\
\hline Age, years & $65.4 \pm 10.4$ & $63.5 \pm 8.7$ & 0.61 \\
\hline Male gender, n (\%) & $62(68.1)$ & $45(69.2)$ & 0.56 \\
\hline Body mass índex, $\mathrm{Kg} / \mathrm{m}^{2}$ & $26.9 \pm 4.3$ & $27.8 \pm 4.5$ & 0.11 \\
\hline Current smoking, n (\%) & $25(27.5)$ & $18(27.7)$ & 0.93 \\
\hline Hypertension, n (\%) & $50(54.9)$ & $33(50.8)$ & 0.77 \\
\hline Dyslipidemia, n (\%) & $55(60.4)$ & $37(56.9)$ & 0.88 \\
\hline Diabetes, n (\%) & $30(33)$ & $19(29.2)$ & 0.76 \\
\hline Insulin use & $7(7.7)$ & $5(7.7)$ & $>0.99$ \\
\hline Previous infarction, n (\%) & $69(75.8)$ & $50(76.9)$ & 0.88 \\
\hline Previous percutaneous coronary intervention, n (\%) & $6(6.6)$ & $5(7.7)$ & 0.86 \\
\hline Clinical presentation, $\mathrm{n}(\%)$ & & & 0.17 \\
\hline Stable angina & $50(54.9)$ & $34(52.3)$ & \\
\hline Unstable angina & $26(28.6)$ & $19(29.2)$ & \\
\hline Silent ischemia & $24(26.4)$ & $12(18.5)$ & \\
\hline Left ventricular ejection fraction & $48.6 \pm 13.7$ & $39.5 \pm 11.8$ & 0.04 \\
\hline Number of affected vessels, n (\%) & & & 0.88 \\
\hline One vessel & $16(17.6)$ & $9(13.8)$ & \\
\hline Two vessels & $42(46.2)$ & $31(47.7)$ & \\
\hline Three vessels & $33(36.2)$ & $25(38.5)$ & \\
\hline Collateral flow grade to the left anterior descending artery & & & 0.03 \\
\hline 1 or $2+$ & $36(39.6)$ & $35(53.8)$ & \\
\hline 3 or $4+$ & $55(60.4)$ & $30(46.2)$ & \\
\hline
\end{tabular}

Table 2

Frequency of major adverse cardiovascular events in three years.

\begin{tabular}{lccc}
\hline & G1 $(\mathbf{n}=\mathbf{9 1})$ & $\mathbf{G 2}(\mathbf{n}=\mathbf{6 5})$ & P-value \\
\hline Death, $\mathrm{n}(\%)$ & $2(2.2)$ & $5(7.7)$ & 0.13 \\
Myocardial infarction, $\mathrm{n}(\%)$ & $1(1.1)$ & $1(1.5)$ & $>0.99$ \\
New revascularization, $\mathrm{n}(\%)$ & $6(6.6)$ & $5(7.7)$ & $>0.99$ \\
Coronary artery bypass graft surgery, $\mathrm{n}(\%)$ & 2 & 2 & \\
Percutaneous coronary intervention, $\mathrm{n}(\%)$ & 4 & 3 & \\
Congestive heart failure, $\mathrm{n}(\%)$ & $3(3.3)$ & $10(15.3)$ & 0.02 \\
Composite clinical events, $\mathrm{n}(\%)$ & $11(12.1)$ & $20(30.8)$ & $<0.01$ \\
\hline
\end{tabular}

in patients with evidence of ischemia or myocardial viability at the expense of a significant reduction in congestive heart failure episodes and non-significant decrease in mortality. Single-digit restenosis of the left anterior descending artery is compatible with results found in studies using similar DES, ${ }^{9}$ and it was a factor that did not affect the difference of composite clinical events between the two groups.
Biological and anatomical aspects are known as myocyte-protective factors in a possible coronary occlusion: ischemic preconditioning and collateral circulation to the target vessel. The ischemic preconditioning is a biomolecular phenomenon that protects the myocytes through the occlusion and repeated reperfusion of a coronary artery, correcting, through complex mechanisms intrinsic to the cardiac cell, and regardless of 
the collateral circulation, the mitochondrial intracellular adaptation to face the permanent ischemia due to vessel occlusion. ${ }^{19,20}$ The collateral circulation to the occluded vessel is undoubtedly a key anatomical factor in the overall or partial preservation of the heart muscle contractility in the area irrigated by the vessel with chronic coronary occlusion. ${ }^{21,22}$ However, in order to be effective, this collateral circulation should be recruited early and effectively, providing blood flow to the occluded vessel. ${ }^{22}$ In the present patients, left ventricular function was better in the group with ischemia/myocardial viability when compared to the group without it, possibly associated with better irrigation of the region.

Safley et al. ${ }^{23}$ evaluated 2,608 patients with onevessel chronic coronary occlusion, divided according the treated coronary: left anterior descending artery in 936 cases $(36 \%)$, left circumflex artery in 682 cases (26\%), and right coronary artery in 990 (38\%). Procedural success was obtained, respectively, in $77 \%, 76 \%$, and $72 \%$. When comparing the five-year evolution in the three groups, a better clinical outcome was observed in patients who attained successful vs. unsuccessful recanalization of the left anterior descending artery (88.9\% vs. $80.2 \%$; $\mathrm{P}<0.001)$. This was not observed with the left circumflex artery $(86.1 \%$ vs. $82.1 \%$; P $=0.21)$ or right coronary artery $(87.7 \%$ vs. $84.9 \% ; \mathrm{P}=$ $0.23)$. The authors concluded that if the benefit occurs only in patients who attained success in the left anterior descending artery, it would be necessary to stringently select cases for $\mathrm{PCl}$ in patients with one-vessel chronic coronary occlusion. However, Mehran and Dangas, ${ }^{11}$ in a corresponding editorial, ${ }^{23}$ argued that the absence of data regarding evaluation of ischemia/myocardial viability, among other considerations, may have affected the conclusions of that study.

Another important clinical aspect is the combination of chronic coronary occlusion of a major vessel with multivessel coronary artery disease. A recent report ${ }^{24}$ demonstrated that, in this anatomical condition, the clinical importance of the complete revascularization is essential for clinical symptom and survival improvement, particularly in patients with ischemia or myocardial viability. However, the complete functional revascularization has been proven to be as effective in preventing clinical events in the long-term as the full anatomical revascularization. ${ }^{25,26}$ The concept of functional percutaneous revascularization in patients with multivessel coronary artery disease was explored in the Fractional flow reserve versus Angiography in Multivessel Evaluation (FAME) study, ${ }^{27}$ in which the physiological-functional evaluation of coronary artery obstructive lesions using the fractional flow reserve reduced adverse clinical outcomes and operational costs. The fractional flow reserve started to be indicated in the North-American guideline ${ }^{14}$ as class I, level A of evidence, and in the European guideline, ${ }^{13}$ as class Ila, level A of evidence. In the present study, it was not possible to use fractional flow reserve, which certainly could add more precise functional information regarding obstructive coronary lesions in the present patients with multivessel coronary artery disease.

The use of DES in the right coronary artery and left circumflex artery in patients with multivessel coronary artery disease, in the present study, was directed to non-diabetic patients with focal lesions, in vessels with a diameter $>2.75 \mathrm{~mm}$, which is in accordance with the methods and results of the Italian multicenter study. ${ }^{28}$ This strategy of using the DES and BMS side by side in patients with multivessel coronary artery disease, particularly the indication of these endoprostheses according to the likelihood of lower or greater restenosis, still remains as a current conduct, legitimized, for instance, at the recently published Dutch study based on the criteria of the National Institute for Clinical Excellence (NICE). ${ }^{29}$

The present findings expand the knowledge regarding the assessment of ischemia and myocardial viability before the percutaneous procedure in a specific population of patients with chronic coronary occlusion of the left anterior descending artery proximal segment, treated with DES, adding this information to that obtained by other studies that presented similar results. ${ }^{24,30-32}$

\section{Limitations of the study}

This study has several limitations, including: 1) retrospective and single-center design, 2) small sample size, 3) fractional flow reserve was not used in the evaluation of lesions in patients with multivessel disease, 4) clinical information was obtained in the long-term by telephone contact or with the attending physician.

\section{CONCLUSIONS}

The treatment of chronic coronary occlusion in the left anterior descending artery proximal segment with DES, in patients with evidence of ischemia or myocardial viability, reduces long-term clinical events. The choice of percutaneous revascularization depends on a number of factors, and must be based on adequate patient selection, careful evaluation of the anatomical aspects of the lesion, availability of devices dedicated to the management of occlusions, and availability of DES.

\section{CONFLICTS OF INTEREST}

The authors declare no conflicts of interest.

\section{REFERENCES}

1. Klein LW, Weintraub WS, Agarwal JB, Schneider RM, Seelans PA, Katz RI, et al. Prognostic significance of severe narrowing of the proximal portion of the left anterior descending coronary artery. Am J Cardiol. 1986;58(1):42-6.

2. Reifart N. Percutaneous revascularisation of coronary chronic total occlusion. Minerva Med. 2011;2012(5):391-7. 
3. Shah PB. Management of coronary chronic total occlusion. Circulation. 2011;123(16):1780-4.

4. Serruys PW, Kutryk MJB, Ong ATL. Coronary-artery stents. N Engl J Med. 2006;354(5):483-95.

5. Bangalore S, Kumar S, Fusaro M, Amoroso N, Kirtane AJ, Byrne RA, et al. Outcomes with various drug eluting or bare metal stents in patients with diabetes mellitus: mixed treatment comparison analysis of 22, 844 patient years of follow-up from randomised trials. BMJ. 2012;345:e5170.

6. Tanajura LF, Feres F, Siqueira DA, Abizaid A, Fraulob SM, Fucci A, et al. Influência dos stents farmacológicos na seleção de pacientes diabéticos tratados por meio de intervenção coronária percutânea. Rev Bras Cardiol Invasiva. 2010;18(2):151-6.

7. Lasave LI, Costa Jr JR, Abizaid A, Feres F, Sanchez A, Costa R, et al. Stents farmacológicos versus não-farmacológicos para o tratamento de pacientes uniarteriais portadores de lesão em artéria descendente anterior: seguimento clínico de dois anos. Rev Bras Cardiol Invasiva. 2008;16(1):24-30.

8. Pimentel Filho WA, Correia MB, Bocchi EA, Di Nucci T, Fiorotto WB, Barroso LM, et al. Lesão no segmento proximal da artéria coronária descendente anterior: resultados entre o tratamento cirúrgico (mamária) e o percutâneo (stent com fármaco). Rev Bras Cardiol Invasiva. 2007;15(4):370-7.

9. Colmenarez HJ, Escaned J, Fernández C, Lobo L, Cano S, Del Angel JG, et al. Efficacy and safety of drug-eluting stents in chronic total coronary occlusion recanalization: a systematic review and meta-analysis. J Am Coll Cardiol. 2010;55(17):1854-66.

10. Muramatsu T. Aspectos clínicos e técnicos atuais das abordagens anterógrada e retrógrada da intervenção coronária percutânea para a oclusão crônica. Rev Bras Cardiol Invasiva. 2012;20(1):89-98.

11. Mehran R, Dangas GD. Revascularization of a chronically occluded left anterior descending artery: is it worth all the effort? JACC Cardiovasc Interv. 2008;1(3):303-4.

12. Mattos LA, Lemos Neto PA, Rassi A Jr, Marin-Neto JA, Sousa AGMR, Devito FS, et al. Diretrizes da Sociedade Brasileira de Cardiologia - Intervenção Coronária Percutânea e Métodos Adjuntos Diagnósticos em Cardiologia Intervencionista (II Edição - 2008). Arq Bras Cardiol. 2008;91(4 Supl.1):1-58.

13. Wijns W, Kolh P, Danchin N, Di Mario C, Falk V, Folliguet T, et al. Guidelines on myocardial revascularization. The Task Force on Myocardial Revascularization of the European Society of Cardiology (ESC) and the European Association for CardioThoracic Surgery (EACTS). Eur Heart J. 2010;31(20):2501-55.

14. Levine GN, Bates ER, Blankenship JC, Bailey SR, Bittl JA, Cercek B, et al. 2011 ACCF/AHA/SCAI Guideline for Percutaneous Coronary Intervention: a report of the American College of Cardiology Foundation/American Heart Association Task Force on Practice Guidelines and the Society for Cardiovascular Angiography and Interventions. Circulation. 2011;124(23):e574-651.

15. Chareonthaitawee $P$, Gersh BJ, Panza JA. Is viability imaging still relevant in 2012? JACC Cardiovasc Imaging. 2012;5(5):550-8.

16. Shabana A, El-Menyar A. Myocardial viability: what we knew and what is new. Cardiol Res Pract. 2012:607486.

17. Gerber BL, Rousseau MF, Ahn SA, Le Polain de Waroux BP, Pouleur AC, Phlips T, et al. Prognostic value of myocardial viability by delayed-enhanced magnetic resonance in patients with coronary artery disease and low ejection fraction. J Am Coll Cardiol. 2012;59(9):825-35.

18. Hoffmann R, Marwick TH, Poldermans D, Lethen H, Ciani R, van der Meer $\mathrm{P}$, et al. Refinements in stress echocardiographic techniques improve inter-institutional agreement in interpretation of dobutamine stress echocardiograms. Eur Heart J. 2002;23(10):821-9.
19. Yellon DM, Downey JM. Preconditioning the myocardium: from cellular physiology to clinical cardiology. Physiol Rev. 2003;83(4):1113-51.

20. Pimentel WA, Martinez EE, Ambrose JA, Mathias JW, Arruda A, Horta PE, et al. Human myocardium preconditioning during successive balloon inflations: irrelevant influence of both collateral recruitment and clinical pre-intervention interference. Eurolntervention. 2006;2(3):345-50.

21. Petronio AS, Baglini R, Limbruno U, Mengozzi G, Amoroso G, Cantarelli A, et al. Coronary collateral circulation behaviour and myocardial viability in chronic total occlusion treated with coronary angioplasty. Eur Heart J. 1998;19(11):1681-7.

22. Traupe T, Gloekler S, de Marchi SF, Werner GS, Seiler C. Assessment of the human coronary collateral circulation. Circulation. 2010;122(12):1210-20.

23. Safley DM, House JA, Marso SP, Grantham JA, Rutherford BD. Improvement in survival following successful percutaneous coronary intervention of coronary chronic total occlusions: variability by target vessel. JACC Cardiovasc Interv. 2008;1(3):295-302.

24. Valenti R, Migliorini A, Signorini U, Vergara R, Parodi G, Carrabba $N$, et al. Impact of complete revascularization with percutaneous coronary intervention on survival in patients with at least one chronic total occlusion. Eur Heart J. 2008 29(19):2336-42.

25. Pimentel Filho WA, Ascer E, Büchler JR, Assis SF, Hirschfeld R, Soares Neto $M M$, et al. Limites anatômicos para a realização de angioplastia na doença coronária multiarterial. Arq Bras Cardiol. 1992;58(1):1-4.

26. Ong ATL, Serruys PW. Complete revascularization: coronary artery bypass graft surgery versus percutaneous coronary intervention. Circulation. 2006;114(3):249-55.

26. Kirschbaum SW, Springeling T, Boersma E, Moelker A, Giessen WJ, Serruys PW, et al. Complete percutaneous revascularization for multivessel disease in patients with impaired left ventricular function. JACC Cardiovasc Interv. 2010;3(4):392-400.

27. Tonino PAL, Fearon WF, De Bruyne B, Oldroyd KG, Leesar MA, Ver Lee PN, et al. Angiographic versus functional severity of coronary artery stenoses in the FAME study: fractional flow reserve versus angiography in multivessel evaluation. J Am Coll Cardiol. 2010;55(25):2816-21

28. Varani E, Saia F, Balducelli M, Guastaroba P, Marrozzini C, Tarantino $F$, et al. Percutaneous treatment of multivesse coronary disease in the drug eluting stent era: comparison of bare-metal stents, drug-eluting stents and a mixed approach in a large multicentre registry. Eurolntervention. 2007;2(4): 474-80.

29. Beijk MA, Koch KT, Tijssen JG, Henriques JP, Baan J, Vis MM, et al. A retrospective analysis of consecutive patients undergoing nonurgent percutaneous coronary intervention comparing bare metal stents with drug-eluting stents using the National Institute for Clinical Excellence criteria. Coron Artery Dis. 2011;22(1):32-9.

30. Bonow RO, Maurer G, Lee KL, Holly TA, Binkley PF, DesvigneNickens $P$, et al. Myocardial viability and survival in ischemic left ventricular dysfunction N Engl J Med. 2011;364(17): 1617-25.

31. Sadeghian H, Majd-Ardakani J, Lotfi-Tokaldany M. Assessment of myocardial viability: selection of patients for viability study and revascularization. J Teh Univ Heart. 2009;1(1):5-15.

32. Hoye A, Shah N, Ismail H, Khan F, Ahmed D, Ungvari T. 10-Year survival of patients with a chronic total occlusion on coronary angiography is poor particularly in those without evidence of myocardial viability. J Am Coll Cardiol. [Internet]. 2011 [cited 2013 Mar 18];57(14s1):E1630. Available from: http://content.onlinejacc.org/article.aspx?articleid=1145994 